\title{
The Influence of Subjective Norms and Perceived Behavioural Control Intent to use Electronic Parking
}

\author{
Indriati Rochmah Darmayanti \\ Department of Accounting \\ Universitas Airlangga \\ Suarabaya, Indonesia \\ indrirochmah@gmail.com
}

\author{
Noorlailie Soewarno \\ Department of Accounting \\ Universitas Airlangga \\ Surabaya, Indonesia \\ noorlailie@gmail.com \\ Isnalita \\ Department of Accounting \\ Universitas Airlangga \\ Surabaya, Indonesia \\ isnalita@feb.unair.ac.id
}

\begin{abstract}
The purpose of this study is to examine the effect of subjective norms and perceived behavioural control on the intention to use electronic parking with electronic money. The analysis in this study used multiple linear regression analysis with 43 respondents. The findings indicate that: (1) subjective norms have a significant influence on the intention to use electronic parking and (2) perceived behaviour control has a significant influence on the intention to use electronic parking.
\end{abstract}

Keywords-subjective norms; perceived behavioural control and electronic parking.

\section{INTRODUCTION}

An electronic parking meter system is a system that accepts one type of coin or other payment devices. Electronic parking meters consist of resources that may be a type of solar power, as well as, have a terminal for connection to an external power source. Electronic parking meter systems also have microprocessors with the memory connected to the power supply. The electronic screen connects to the microprocessor and displays related information for meters. This electronic parking meter system also uses a direct cable connection or infrared transmission to transfer its data [1], [2].

Boston [3], Oklahoma [4], Houston [5], and Chicago [6] have, implemented an electronic meter parking machine using a kind of electronic money or coins to pay for it, while only in Indonesia was an example recently implemented in the city of Surabaya, in September 2017.

The city of Surabaya implements electronic parking to minimize parking attendant frauds that alters parking fees above the specified tariff, for example in Surabaya parks or in areas visited by many people. In the parking ticket for the motor printed only Rp. 2,000, but the parking attendant changed the tariff of Rp 3,000 to Rp 5,000. As for the car tariff, determined by the government for Rp. 3000, the parking attendant officers charge Rp 5,000 to Rp 10,000 for one-time parking. In addition, the case is that some parking attendants do not provide parking tickets to motorists, whereas the vehicle users who parked have the right to the parking ticket.

In addition to minimizing fraud, this electronic parking can support the movement of Bank Indonesia (BI), which is usually called the National Non-Cash Movement program, because the payment of electronic parking is using electronic money issued by banks [7]. Electronic money is an increasingly used means of payment, both in Indonesia and other countries. Countries that develop electronic money include Japan [8], Sweden [9], Turkey [10], Singapore, Hong kong, Malaysia [11] and others. This can reduce the use of cash and increase the use of electronic money in the form in accordance with the regulations of each country. Indonesia is a developing country, different from developed countries in terms of electronic money usage. The cultural aspect of public confidence in the use of cash is higher than electronic money. Consumers should be encouraged to use electronic money in making any payments, especially to pay for electronic parking, because it not only benefits the government alone, but this case, Bank Indonesia (BI) as the regulator will be able to save money in making money and also reduce the demand for cash. This is due to the fact that, the use of electronic money is safer 
and more effective with much less risk than the use of cash [7].

The problem with this study is the low number of customers, in the use of electronic parking using electronic money. The purpose of this study is to examine the effect of subjective norms and perceived behavioural control on the intention to use electronic parking with electronic money, in order to influence the customer in its use.

\section{LITERATURE REVIEW}

\section{A. Parking Meter}

Parking meters are a tool used to measure the length of time a vehicle has parked in a location for. This tool is usually paired with a roadside parking location. The owner of the vehicle is required to press the button when the parking starts, and after parking the owner of the vehicle must press it again at the end of their parking. This tool will provide information related to the number of parking fees that must be paid by the owner of the vehicle directly inserted into the meter parking tool. This tool is in urgent need and awareness of law enforcement for violators, because this tool is placed on the side of the road without any officer guard. Another type of tool requires the vehicle owner to determine the length of parking time by inserting a coin into the meter's parking machine. At the specified clock, the tool will sound an automatic alarm indicating the parking time has run out. If the alarm sounds and the owner of the vehicle has not moved the vehicle or inserted a new coin, then if there is a patrol the vehicle owner will be charged a ticket sanction [1]-[6].

\section{B. Electronic Money}

[10] explain that the phenomenon of electronic money was first investigated by the European Central Bank in 1993 and the report was published in 1994. There have been some previous studies that mention that some countries have applied it before the 1990s [9], [12]. In the development of the banking world, electronic money is a product with increased utilization. Several studies have begun to discuss electronic money [8], [10], [13]-[15]. In Indonesia, the banking authorities provide support to the community in using electronic money as a way to make transactions.

There are several definitions that explain electronic money. BI Regulation no. (1) is placed on the basis of the money advanced by the bondholder to the company or issuer, (2) the value of money deposited electronically in the media such as servers or chips, (3) are used as instruments of payment to non-electronic issuers, and (4) the value of money paid by holders and managed by non-payment issuers as referred to in banking regulations. [14] states that electronic money covers all non-cash and paperless payment instruments, such as plastic cards and direct transfers, and all money transactions via electronic channels such as ATMs, electronic funds transfer at point of sale, telephone, fax and internet.

\section{TPB}

TPB is a theory developed from the theories of reasoning (TRA) by [16] using the basic assumption that humans are creatures with the power of reason to decide what behaviours will be taken consciously and consider all available information. Furthermore, [17] develops TRA by adding a construct, the perceived behavioural control (PBC) variable, which affects interest and behaviour. Various studies have tried to apply TPB in the banking sector, for example, the TPB application on internet banking [18]-[21]. The TPB research by [22] found that a person makes a decision on his actions by using systematic information obtained by himself. This theory states that one's intentions are influenced by three independent elements, including attitudes (positive and negative evaluations in doing something), subjective norms (pressure or expectation to do something or not), and perceptions of social behaviour. PBC is an ease or difficulty in behaving [17]. Furthermore, a person's attitude is shaped by the person's greatest trust, while subjective norms are established through normative beliefs that represent the perceptions of the nearest person about the preference of one's involvement in a particular behaviour. PBC is influenced by a belief about whether a person has access to the necessary resources including the time and skills to perform certain behaviours [23].

\section{HYPOTHESIS}

\section{A. The Effect of Subjective Norms on Intent to Use Electronic Parking}

Subjective norms are also based on prominent beliefs, a normative belief of a social nature, whether the respondent's specific thought states that they should or should not take certain action [24]. These subjective norms are also called normative beliefs [25]. Subjective norms are essentially social impacts created by someone with the closest connection (family, friends, colleagues etc.) who may have an influence on decision making. Theoretically, subjective norms influence the interest of performing certain actions [17]. In this study, behavioural interest was demonstrated by the intention of using electronic parking. Co-workers, friends, or family can influence a person's intentions to use electronic parking even the environment can also affect one's intentions to use electronic parking as a parking facility, especially in Surabaya. Based on this explanation, this study proposes one hypothesis, namely: $\mathrm{H}_{1}$ : Subjective norms will be able to increase the intention to use electronic parking.

\section{B. The Effect of PBC on Intent to Use Electronic Parking}

$\mathrm{PBC}$ is a factor that refers to the ease or difficulty in performing certain behaviours and assumes experience in anticipating obstacles [17]. The easier the use of electronic parking, the more people are interested in using it. They will use electronic money to use electronic parking facilitated by the Surabaya City Government. Based on this explanation, this 
research proposes hypotheses two, namely: $\mathrm{H}_{2}$ : $\mathrm{PBC}$ will be able to increase the intention in using electronic parking.

\section{METHOD}

\section{A. Samples and Sampling Techniques}

This study conducted the distribution of questionnaires using online means via Google Drive. The result is 43 respondents, consist of 18 men and 25 women, drawn in Surabaya with purposive sampling technique and accidental sampling technique. The sample selection in Surabaya is based on the consideration of ease of getting information and proximity to the researcher (convenience sampling). The measurement scale used is the Likert scale with the following criteria: (1) Residents of Surabaya City. The analysis technique used is Multiple Linear Regression Analysis. In data processing, research using WarpPLS 6.0 software.

TABLE I. CONSTRUCT ITEM

\begin{tabular}{|c|c|c|}
\hline $\begin{array}{c}\text { Latent } \\
\text { Variables }\end{array}$ & Indicator & Sources \\
\hline \multirow[t]{2}{*}{$\begin{array}{l}\text { Subjective } \\
\text { Norm (SN) }\end{array}$} & $\begin{array}{l}\text { SN1: People who matter to me } \\
\text { (like family, friends, friends and } \\
\text { spouses) influence usage } \\
\text { behaviour }\end{array}$ & \multirow[t]{2}{*}{$\begin{array}{l}{[16],[21],[22], \text { and }} \\
{[26] .}\end{array}$} \\
\hline & $\begin{array}{l}\text { SN2: The social environment } \\
\text { influences the usage behaviour }\end{array}$ & \\
\hline \multirow{3}{*}{$\begin{array}{l}\text { Perceived } \\
\text { Behavioural } \\
\text { Control } \\
\text { (PBC) }\end{array}$} & $\begin{array}{l}\text { PBC1: Have enough knowledge } \\
\text { to use }\end{array}$ & \multirow{3}{*}{$\begin{array}{l}\text { [16], [17], [21], [24], } \\
\text { and [27]. }\end{array}$} \\
\hline & $\begin{array}{l}\text { PBC2: Have enough ability to } \\
\text { use }\end{array}$ & \\
\hline & PBC3: Can use & \\
\hline \multirow{3}{*}{$\begin{array}{l}\text { Intent To } \\
\text { Use (ITU) }\end{array}$} & ITU1: Plan to use & \multirow{3}{*}{$\begin{array}{l}\text { [16], [21], [22], [24], } \\
\text { [26], and [28]. }\end{array}$} \\
\hline & ITU2: Intend to use & \\
\hline & ITU3: Trying to use & \\
\hline
\end{tabular}

\section{RESULT}

\section{A. Reliability and Validity}

SN (SN1: 0.939 and SN2: 0.939); PBC (PBC1: 0.943; PBC2: 0.946; PBC3: 0.904) and ITU (ITU1: 0.878; ITU2: 0.905; ITU3: 0.931). From the following results have proved that the data is valid because if the value $<0.7$ for confirmatory research, while the value $>0.6$ is still acceptable in exploratory research with average variance extracted (AVE) then the data is said to be valid.

The data is quite reliable.

\section{B. Hypothesis testing}

TABLE II. HyPOTHESIS TESTING RESULTS

\begin{tabular}{|c|c|c|c|}
\hline Hypothesis & $\begin{array}{c}\text { Coefficient } \\
(\beta)\end{array}$ & P-Value & $R^{2}$ \\
\hline $\begin{array}{l}\text { Subjective norms } \\
\text { will be able to } \\
\text { increase the } \\
\text { intention to use } \\
\text { electronic } \\
\text { parking. }\end{array}$ & 0.34 & $P<.01$ & \multirow{2}{*}{0.63} \\
\hline $\begin{array}{l}\text { Perceived } \\
\text { behaviour control } \\
\text { will increase the } \\
\text { intention of using } \\
\text { electronic } \\
\text { parking. }\end{array}$ & 0.55 & $\mathrm{P}<.01$ & \\
\hline
\end{tabular}

There are two hypotheses in this study: Hypothesis 1 in this study states that subjective norms will be able to increase the intention to use electronic parking. The results of hypothesis testing conclude that subjective norms can increase the intention to use electronic parking $(\beta=0.34 ; \mathrm{P}<0.01)$. This proves that hypothesis 1 is acceptable. While the hypothesis 2 in this study states that Perceived Behavioral Control will be able to increase the intention to use electronic parking. The result of the hypothesis testing concluded that Perceived Behavioral Control can increase the intention to use electronic parking $(\beta=0.55 ; \mathrm{P}<0.01)$. This proves that hypothesis 2 is acceptable.

The value of the coefficient of multiple determinants $\left(\mathrm{R}^{2}\right)$ of 0.63 shows $63 \%$, which means: Intention to use Electronic Parking Subjective Norm (X1) and Perceived Behavioral Control (X2) is $37 \%$ due to other factors not included in the research.

From the conclusion of this hypothesis test, in accordance with the hypothesis it is estimated that both have a significant influence on the intention to use electronic parking.

\section{DISCUSSION}

The subjective norm represents the perception of the nearest person about whether or not to do it. This study shows the similarity of results that subjective norms have a positive and significant influence on the intention to use electronic parking. In general, perceived control behaviours can significantly improve behavioural intentions. It is proven in this study that the perceived behaviour control is able to significantly increase the intention to use electronic parking. From the results of this study in accordance with previous research that subjective norms and perceived behavioural control can increase the intention to do something [7, 19].

The theory states that one's intentions are influenced by three independent elements, including attitudes (positive and negative evaluations in doing something), subjective norms (pressure or expectation to do something or not), and perceptions of social behaviour. This is in accordance with the results of the researcher that subjective norms and perceived behavioural control significantly influence one's intentions in using electronic parking with electronic money. 


\section{CONCLUSION}

The purpose of this study is to examine the effect of subjective norms and perceived behavioural control on the intention to use electronic parking using the electronic money, in order to influence the customer in the use of electronic parking using electronic money. In this study shows the similarity of results that subjective norms have a positive and significant influence on the intention to use electronic parking. In general, perceived control behaviours can significantly improve behavioural intentions. It is proven in this study that the perceived behaviour control is able to significantly increase the intention to use electronic parking.

\section{VIII.LIMITATIONS OF RESEARCH AND AdVICE}

Limitations of this study which are on the object of this study is limited to the city of Surabaya. Further research should include moderate variables or control variables, such as culture and attitudes and moderation variables, such as gender and age. It is suggested that further research use a more complex model so that the point of view is not only limited to the use of TPB and it is also suggested to have more respondents.

\section{REFERENCES}

[1] J. P. Jacobs and V. G. Yost, "Electronic parking meter," ed: Google Patents, 2001.

[2] G. W. Speas, "Parameter control system for electronic parking meter," ed: Google Patents, 1990.

[3] Y. Geng and C. G. Cassandras, "A new "smart parking” system based on optimal resource allocation and reservations," in Intelligent Transportation Systems (ITSC), 2011 14th International IEEE Conference on, 2011, pp. 979-984: IEEE.

[4] F. C. Leung, "Programmable parking meter and integrated paging transmitter," ed: Google Patents, 2012.

[5] A. S. Albers, "Many many many many parking spaces," Rice University, 1999.

[6] M. Dayan, "System and Method for Determining and Reserving Available Parking," ed: Google Patents, 2011.

[7] N. Farida, E. Ardyan, and N. Nuryakin, "Gender Differences In Interest in Using Electronic Money: An Application of Theory Planned Behavior," Int. Rev. of Manage. and Mark., vol. 6, no. 4, 2016.

[8] H. Fujiki and M. Tanaka, "Currency demand, new technology, and the adoption of electronic money: Micro evidence from Japan," Econ. let., vol. 125 , no. 1 , pp. 5-8, 2014.

[9] C. Lindén and H. Block, "Sealing electronic money in Sweden," Comp. \& Sec., vol. 1, no. 3, pp. 226-230, 1982

[10] G. Gürkaynak and I. Yilmaz, "Regulating payment services and electronic money: A comparative regulatory approach with a specific focus on Turkish legislation," Comp. Law \& Sec. Rev., vol. 31, no. 3, pp. 401-411, 2015
[11] S. Hidayati, I. Nuryanti, A. Firmansyah, A. Fadly, and I. Y. Darmawan, "Operasional e Money," Jakarta, Indonesia: Bank Indonesia, 2006.

[12] P. K. Coats, "A banker's use of simulation and artificial intelligence for assessing the economics of electronic money networks," Eur. j. of operat. res., vol. 41, no. 3, pp. 290-301, 1989.

[13] J. J. McAndrews, "E - Money and Payment System Risks," Contem. Econ. Pol., vol. 17, no. 3, pp. 348-357, 1999.

[14] S. Singh, "Electronic money: understanding its use to increase the effectiveness of policy," Telecomm. Pol., vol. 23, no. 10-11, pp. 753773, 1999.

[15] E. Solomon, "What should regulators do about consolidation and electronic money?," J. of Bank. \& Fin., vol. 23, no. 2-4, pp. 645-653, 1999.

[16] C. Liao, J.-L. Chen, and D. C. Yen, "Theory of planning behavior (TPB) and customer satisfaction in the continued use of e-service: An integrated model," Comp. in hum. behav., vol. 23, no. 6, pp. 2804 2822, 2007.

[17] I. Ajzen, "The theory of planned behavior," Organ. behav. and hum. dec. proc., vol. 50, no. 2, pp. 179-211, 1991.

[18] M.-C. Lee, "Factors influencing the adoption of internet banking: An integration of TAM and TPB with perceived risk and perceived benefit," Electr. comm. res. and appl., vol. 8, no. 3, pp. 130-141, 2009.

[19] D. Maduku, "Predicting retail banking customers' attitude towards Internet banking services in South Africa," Sout. Afr. Bus. Rev., vol 17, no. 3, pp. 76-100, 2013.

[20] W. Nasri and L. Charfeddine, "Factors affecting the adoption of Internet banking in Tunisia: An integration theory of acceptance mode and theory of planned behavior," The J. of Hi. Technol. Manage. Res., vol. 23, no. 1, pp. 1-14, 2012

[21] Y.-Y. Shih and K. Fang, "The use of a decomposed theory of planned behavior to study Internet banking in Taiwan," Inter. res., vol. 14, no. 3 , pp. 213-223, 2004.

[22] J. H. Greenslade and K. M. White, "The prediction of above-average participation in volunteerism: A test of the theory of planned behavior and the volunteers functions inventory in older Australian adults," The J. of Soc. Psychol., vol. 145, no. 2, pp. 155-172, 2005

[23] M. Conner and C. J. Armitage, "Social psychological models of food choice," Front. in Nutri. Sci., vol. 3, p. 41, 2006.

[24] R. East, "Investment decisions and the theory of planned behaviour," J. of Econ. Psychol., vol. 14, no. 2, pp. 337-375, 1993.

[25] S. Y. Yousafzai, G. R. Foxall, and J. G. Pallister, "Explaining interne banking behavior: Theory of reasoned action, theory of planned behavior, or technology acceptance model?," J. of app. soc. psychol., vol. 40, no. 5, pp. 1172-1202, 2010.

[26] S. Taylor and P. A. Todd, "Understanding information technology usage: A test of competing models," Inform. sys. res., vol. 6, no. 2, pp. 144-176, 1995.

[27] C. Ruiz Mafe, S. Sanz Blas, and J. Fernando Tavera-Mesías, "A comparative study of mobile messaging services acceptance to participate in television programmes," J. of serv. Manage., vol. 21, no. 1, pp. 69-102, 2010.

[28] G. Rigopoulos and D. Askounis, "A TAM Framework to Evaluate Users Ã $\uparrow$ Â Â Perception towards Online Electronic Payments," The J. of Inter. Bank. and Comm., vol. 12, no. 3, pp. 1-6, 1970. 